\title{
REVIEW
}

\section{Genomic regions under selection for important traits in domestic horse breeds}

\author{
Xuexue LIU ${ }^{1,2}$, Yuehui MA ${ }^{1,2}$, Lin JIANG $(\bowtie)^{1,2}$ \\ 1 Institute of Animal Science, Chinese Academy of Agricultural Sciences, Beijing 100193, China \\ 2 CAAS-ILRI Joint Laboratory on Livestock and Forage Genetic Resources, Institute of Animal Science, \\ Chinese Academy of Agricultural Sciences, Beijing 100193, China
}

\begin{abstract}
Horses were domesticated 5500 years ago, thousands of years later than other domestic animals; however, in this relatively short period, domestic horses have had a great impact on human history by accelerating civilization, revolutionizing warfare and advancing agricultural production. Modern breeding using markerassisted selection has greatly accelerated breeding progress. Therefore, identification of genetic markers underlying the traits of interest in domestic horses is the basis for the modern breeding system. In this review, we present an overview of genetic mapping studies and genome wide analyses to identify the genomic regions targeted by positive selection for four important aspects of horses, coat color, racing performance, gait and height at withers. The $M C 1 R$ locus, for example, has been shown to be the main gene responsible for chestnut color, and the MSTN locus has been shown to control the muscle fiber growth in racing breeds. The missense mutation in DMRT3 is the causal mutation for the alternate gaits in horses. Height at withers, a quantitative trait, was mapped to four major loci (3:105547002, 6:81481064, 9:75550059 and 11:232597 32) that can explain $83 \%$ of the height variations in domestic horses.
\end{abstract}

Keywords horse, coat color, racing performance, gait, height

\section{Introduction}

Horses were first domesticated approximately $5500 \mathrm{BP}^{[1]}$, thousands of years later than other domestic animals, such as cattle, dogs, goats, pigs and sheep. In China, domesticated horses have not been widely found at archeological sites before the Late Shang Dynasty

Received January 22, 2017; accepted March 16, 2017

Correspondence: jianglin@caas.cn (approximately 3300 BP). During this relatively short period, domestic horses have had a great impact on human history by accelerating civilization, revolutionizing warfare and advancing agricultural production. Conversely, human activities have also influenced the recent evolution of domestic horses, especially development of multiple breeds with specific traits through strong selective breeding. Among these phenotypic traits, coat color, locomotion (gaits), racing performance and height at withers are the most important and easily observed domesticated traits. The height at withers was measured from the support surface of the animal to the highest point on its back. Because of the rapid progress in sequencing and genotyping techniques, the horse reference genome assembly was generated from a thoroughbred mare, Twilight $^{[2]}$, and the horse 50K SNP array was developed by the Equine Genome Diversity Consortium ${ }^{[3]}$. In this review, we focus on the recent advances in horse genomics through the mapping of candidate genomic regions targeted by selection during horse domestication. Positive selection, a force that drives the increase in the prevalence of traits that are advantageous or useful for humans, has played a central role in the domestication of animals ${ }^{[4]}$.

\section{Genes and genomic variations under selection for economically important traits}

\subsection{Coat color variation}

Coat color was one of the earliest selection targets during horse domestication. Currently, domestic horses exhibit a wide variation in coat colors ranging from a unified single color to a composite coat (Table 1). Previous genetic studies have shown that coat color variations appeared rapidly during domestication ${ }^{[3]}$, and many genes involved in melanin production and distribution have had an important role in the development of coat color in domesticated animals. MCIR (melanocortin 1 receptor), 
Table 1 Causative mutations for coat coloration in domestic horses

\begin{tabular}{lcccc}
\hline Causative mutation & Breed & Color & Gene ID & Reference \\
\hline 83Ser-Phe & European breeds & Chestnut & $M C 1 R$ & {$[5]$} \\
83Ser-Phe & Morgan and Belgian horses & Chestnut & $M C 1 R$ & {$[3]$} \\
$4.6-\mathrm{kb}$ duplication in intron 6 & Gray horse & Gray & $S T X 17$ & {$[6]$} \\
$1617-$ bp insertion & Dun horse & Dun & $T B X 3$ & {$[7]$} \\
C189T & Mongolian horse & Chestnut & $T Y R P 1$ & {$[8]$} \\
\hline
\end{tabular}

ASIP (agouti signaling protein), TYRP (tyrosine transporter), and PMEL17 (premelanosome protein) are the candidate genes for coat color, and many mutations in these genes associated with variations in coat colors of chickens $^{[9]}$, sheep ${ }^{[10]}$ and pigs ${ }^{[11]}$ have been identified.

In early 1996, a single nonsynonymous mutation (83Ser-Phe) in the MC1R gene, which created a TaqI restriction site in the chestnut allele, was found to be responsible for the chestnut color in horses ${ }^{[5]}$. In Morgan and Belgian horse breeds, it was found that the MC1R missense mutation has been fixed, leading to the chestnutbase coat color ${ }^{[12]}$. The horse 50K SNP array was also used to map the chestnut color in American, Asian and European horses, resulting in identification of a conserved $750 \mathrm{~kb}$ haplotype at the MC1R chestnut allele across all breeds $^{[3]}$. Furthermore, the agouti $(A S I P)$, extension $(M C 1 R)$, and brown (TYRP) loci were detected in European $^{[13]}$ and Przewalski's horses ${ }^{[14]}$.

The gray coat color in horses has been mapped to a 4.6-kb duplication in intron 6 of the STX17 gene (syntaxin17), which is a cis-acting regulatory mutation ${ }^{[6]}$. The gray horses also carry a loss-of-function mutation in the agouti ASIP locus. Meanwhile, in Arabian and Lippizaner horses, the gray allele is associated with the increased risk of melanoma; further analyses reported a copy number expansion of the STX17 gene in melanoma tissues of gray horses ${ }^{[15,16]}$. Therefore, increase in the copy number of the STX17 gene was used by researchers as a marker to assess the risk of melanoma in Quarter horses ${ }^{[17]}$, which makes disease prevention at an early stage possible.

Another example of coat color selection in horses is the wild-type dun coloration caused by a 1617-bp insertion in the $T B X 3$ locus on chromosome $8^{[7]}$. The dun color is the ancestral coat color of equids. A dun individual is mostly pale in color, but carries intensely pigmented primitive markings, most notably, a dorsal stripe. The dun mutation causes radially asymmetric expression of the transcription factor TBX3 in hair follicles, leading to a circumferential distribution of melanocytes in the individual hairs. Polish Konik horses have been reported to carry two new variants in this locus ${ }^{[18]}$.

There are very few mapping studies of the coat color in native Chinese horses. A missense mutation in exon 2 of the TYRP 1 gene was detected in the chestnut color Chinese Mongolian horses ${ }^{[8]}$. The STX17 duplication has been observed in most Chinese indigenous horses, except
Balikun and Guanzhong breeds; however, the frequency of gray coat color in Chinese horses has been found to be relatively low ${ }^{[19]}$.

\subsection{Racing performance}

In the last few hundred years, humans have favored horses with greater strength, racing speed or endurance and have selected specialized horse breeds with excellent racing performance. Racing performance varies among different breeds and is of high economic importance to the modern equine industry. Quarter horses, for example, are famous for their performance in $400 \mathrm{~m}$ sprints, and thoroughbreds, which have been introduced around the world, race distances ranging from 1 to $3.2 \mathrm{~km}$. The famous Akhal Teke horses can compete in endurance races over $160 \mathrm{~km}$. A SINE insertion in the promoter region and a SNP (g.66493737C/T) in the first intron of the MSTN (myostatin) gene have been found to be significantly associated with the fiber type proportions and diameter as well as with the muscle fiber composition in quarter horses ${ }^{[12]}$. Additionally, this mutation was suggested to be more predictive of optimal racing distance in thoroughbreds than a SINE insertion ${ }^{[20]}$. A SNP (g.66493737C/T) in the MSTN gene showed significant association with racing performance; the $\mathrm{C} / \mathrm{C}$ genotype horses are better suited to fast but short-distance races, the $\mathrm{C} / \mathrm{T}$ genotype horses compete favorably in middle-distance races, and the $\mathrm{T} / \mathrm{T}$ genotype horses have greater stamina for longdistance races ${ }^{[21]}$. A larger population of 1396 horses was used in another study to validate the gene in a genomewide association study (GWAS) and an estimated breeding value (EBV) analysis ${ }^{[22]}$. Notably, the MSTN locus was also found in Chinese horse breeds ${ }^{[23]}$. All these studies indicate that the MSTN locus has a pivotal role in race horse performance.

In Chinese horse breeds, six SNPs (g.26T $>$ C, g.156 $\mathrm{T}>\mathrm{C}$, g. $587 \mathrm{~A}>\mathrm{G}$, g. $598 \mathrm{C}>\mathrm{T}$, g. $1485 \mathrm{C}>\mathrm{T}$, g. 2115 $\mathrm{A}>\mathrm{G})$ in the MSTN gene were detected by sequencing ${ }^{[23]}$. Unfortunately, no racing performance association studies have been conducted in these horses and it would, therefore, be meaningful to know whether the MSTN locus is associated with racing performance in Chinese horse breeds.

The MSTN locus is not the only determinant of racing performance in horses. A coevolving gene cluster on 
chromosome 22 has been subjected to strong artificial selection in Korean thoroughbred racing horses, representing a different mechanism from European thoroughbred breeds. This gene cluster contains the RALGAPA2 gene (Ral GTPase-activating protein catalytic alpha subunit 2), which regulates a variety of cellular processes in signal trafficking. The neighboring genes, INSM1 (insulinomaassociated 1), PLDN (pallid), and RIN2 (ras and rab interactor 2), have similar roles in signal trafficking ${ }^{[24]}$.

\subsection{Gaits}

Horse locomotion has also been recurrently selected, in particular, the ability to perform alternate gaits. The alternate gaits are typical characteristics of horse breeds and can be classified into four categories: pace, regular rhythm ambling, lateral ambling and diagonal ambling, according to the pattern of timing and sequence of footfalls. One of the milestones in the horse gait research was published in the journal Nature in 2012. The authors mapped the gait trait to the DMRT3 gene (doublesex and mab-3 related transcription factor 3). The causal mutation results in a premature stop at codon 301 in DMRT3, which has a substantial effect on the ability to perform alternate gait in horses and locomotion in a knockout mouse model ${ }^{[25]}$. Further validation of this mutation was performed in the worldwide horse populations ${ }^{[26]}$. In Finn horses, individuals carrying the AA genotype had better race performance, whereas $\mathrm{CC}$ and $\mathrm{AC}$ individuals appeared to be better adapted for classical riding disciplines ${ }^{[27]}$. In Nordic and Standard bred horses, examples with the AA genotype obtained evaluation of breeding values (EBVs) higher than other genotypes in the same pedigree ${ }^{[28]}$. In Icelandic horses, which are a famous multigaited horse breed, the AA genotype reinforces the coordination of ipsilateral legs, whereas the CA genotype has a negative effect on synchronized movement of diagonal legs ${ }^{[29]}$. In China, Chakouyi, an ancient post horse with the ability to pace, was reported to have a high frequency $(67.2 \%)$ of the DMRT3 mutation $^{[30]}$. In summary, the DMRT3 mutation (the causal mutation for gaits in horses) has practical implications for the breeding and training of multi-gaited horses. Other studies have also reported trot ${ }^{[31]}$, dressage ${ }^{[32]}$ and jump ${ }^{[33]}$ performances of horses.

\subsection{Height at withers}

Height is an easily observed phenotype in the horse and varies markedly in domestic horses, ranging from $80 \mathrm{~cm}$ tall at withers in the Shetland pony to more than $2 \mathrm{~m}$ in Shire and Percheron horses (Table 2). This intraspecies range in heights is only exceeded by the height variations in domestic $\operatorname{dogs}^{[37]}$. A height of $148 \mathrm{~cm}$ at withers is the defined criterion for classifying ponies. Shetland and Debao, two of the most famous pony breeds, have heights less than $100 \mathrm{~cm}$. The heritability of height was estimated to be medium to high in pony breeds. With the development of high-throughput sequencing technology, four loci that can explain $83 \%$ of horse size variations were identified, including 3:105547002, 6:81481064, 9:75550 059 and 11:23259732, as well as four nearby genes also associated with height, LCORL (ligand dependent nuclear receptor corepressor-like), $N C A P G$ (non-SMC condensing I complex subunit G), HMGA2 (high mobility group AThook 2), and ZFAT (zinc finger and AT-hook domain containing $)^{[34]}$. Of the four, loci 3:105547002 can account for $18 \%$ of body size variations ${ }^{[38]}$. This result was further validated in Franches-Montagnes horses ${ }^{[39]}$. In German Warmblood horses, the LCORL/NCAPG locus (3:105547 $002)$ has a strong association with height at withers ${ }^{[40]}$. Additionally, the relative expression levels of LCORL demonstrated a significant association with the size of the horses $^{[41]}$, indicating that this gene could become a potential marker for molecular breeding of height at withers. Two recent papers have reported that missense mutations in $H M G A 2$ (c.83G $>$ A; p.G28E) and $A C A N$ (g. $94370258 \mathrm{G}>\mathrm{C}$ ) have a strong association with dwarfism in Miniature Shetland ponies ${ }^{[35,42]}$.

In Chinese horse breeds, in addition to the HMGA2 locus, $T B X 3$ (T-box 3 ) is most substantially associated with small stature of Debao ponies, a native breed in South-west China, which have potentially unique genetic components underlying their small stature ${ }^{[36]}$. Large deletions in the pseudoautosomal region of chromosome $\mathrm{X} / \mathrm{Y}$ have been associated with dwarfism in Shetland ponies ${ }^{[43]}$.

\section{Adaption to extreme environments}

Animals living on high plateaus have adapted to the highaltitude conditions, such as hypoxia, low temperature, high solar radiation and lack of biological production. The genetic mechanism for adaption to high altitude appears to be more complicated than any other phenotype. In feral Andean horses introduced to the high Andes by the Spanish in the 1500s, EPAS1 (endothelial PAS domain protein 1) coding for a transcription factor involved in the

Table 2 Causative mutations for the height at withers in domestic horses

\begin{tabular}{lcccc}
\hline Causative mutation & Breed & Average height/cm & Gene ID & Reference \\
\hline 3:105547002, 6:81481064, 9:75550059 and 11:23259732 & European & $80-200$ & LCORL, NCAPG, HMGA2, ZFAT & {$[34]$} \\
c.83G $>$ A; p.G28E & Shetland & 80 & HMGA2 \\
ECA8.18101000 and ECA8.18120526 & Debao pony & 106 & TBX3 & {$[35]$} \\
\hline
\end{tabular}


hypoxia-induction-pathway was identified as a significant selection signal ${ }^{[4]}$. Yakutia is among the coldest regions in the Northern Hemisphere, with winter temperatures dropping below $-70^{\circ} \mathrm{C}$; Yakutia horses have lived in this region for six to eight centuries. Using comparative genomics analysis, two candidate genes BARX2 (BARX homeobox 2) and PHIP (pleckstrin homology domain interacting protein) associated with hair development and insulin metabolism, respectively, were identified as contributing to the adaptation of Yakutia horses ${ }^{[45]}$.

\section{Conclusions and prospects}

Recently high-throughput sequencing has contributed greatly to illustrate the genomic mechanisms underlying a variety of economic traits in horse breeds. Some of the newly discovered causative mutations in association to these economic traits have been applied to the progeny test and selective breeding in horse industry. In future, the application of genome selection in horse breeding and the progress of the accurate phenotypic testing for these economic traits as well as the adaptation traits will facilitate the identification of more reliable candidate genetic markers with the function validation and the improvement of the current horse breeds.

Acknowledgements This work was supported by the Agricultural Science and Technology Innovation Program of China (ASTIP-IAS01) and the National Infrastructure of Domestic Animal Resources.

Compliance with ethics guidelines Xuexue Liu, Yuehui Ma, and Lin Jiang declare that they have no conflicts of interest or financial conflicts to disclose.

This article is a review and does not contain any studies with human or animal subjects performed by any of the authors.

\section{References}

1. Outram A K, Stear N A, Bendrey R, Olsen S, Kasparov A, Zaibert V, Thorpe N, Evershed R P. The earliest horse harnessing and milking. Science, 2009, 323(5919): 1332-1335

2. Wade C M, Giulotto E, Sigurdsson S, Zoli M, Gnerre S, Imsland F, Lear T L, Adelson D L, Bailey E, Bellone R R, Blöcker H, Distl O, Edgar R C, Garber M, Leeb T, Mauceli E, MacLeod J N, Penedo M C, Raison J M, Sharpe T, Vogel J, Andersson L, Antczak D F, Biagi T, Binns M M, Chowdhary B P, Coleman S J, Della Valle G, Fryc S, Guérin G, Hasegawa T, Hill E W, Jurka J, Kiialainen A, Lindgren G, Liu J, Magnani E, Mickelson J R, Murray J, Nergadze S G, Onofrio R, Pedroni S, Piras M F, Raudsepp T, Rocchi M, Røed K H, Ryder O A, Searle S, Skow L, Swinburne J E, Syvänen A C, Tozaki T, Valberg S J, Vaudin M, White J R, Zody M C, Lander E S, LindbladToh K. Genome sequence, comparative analysis, and population genetics of the domestic horse. Science, 2009, 326(5954): 865-867

3. McCue M E, Bannasch D L, Petersen J L, Gurr J, Bailey E, Binns M M, Distl O, Guérin G, Hasegawa T, Hill E W, Leeb T, Lindgren G, Penedo M C, Røed K H, Ryder O A, Swinburne J E, Tozaki T,
Valberg S J, Vaudin M, Lindblad-Toh K, Wade C M, Mickelson J R. A high density SNP array for the domestic horse and extant Perissodactyla: utility for association mapping, genetic diversity, and phylogeny studies. PLoS Genetics, 2012, 8(1): e1002451

4. Sabeti P C, Schaffner S F, Fry B, Lohmueller J, Varilly P, Shamovsky O, Palma A, Mikkelsen T S, Altshuler D, Lander E S. Positive natural selection in the human lineage. Science, 2006, 312 (5780): 1614-1620

5. Marklund L, Moller M J, Sandberg K, Andersson L. A missense mutation in the gene for melanocyte-stimulating hormone receptor (MC1R) is associated with the chestnut coat color in horses. Mammalian Genome, 1996, 7(12): 895-899

6. Rosengren Pielberg G, Golovko A, Sundström E, Curik I, Lennartsson J, Seltenhammer M H, Druml T, Binns M, Fitzsimmons C, Lindgren G, Sandberg K, Baumung R, Vetterlein M, Strömberg S, Grabherr M, Wade C, Lindblad-Toh K, Pontén F, Heldin C H, Sölkner J, Andersson L. A cis-acting regulatory mutation causes premature hair graying and susceptibility to melanoma in the horse. Nature Genetics, 2008, 40(8): 1004-1009

7. Imsland F, McGowan K, Rubin C J, Henegar C, Sundström E, Berglund J, Schwochow D, Gustafson U, Imsland P, Lindblad-Toh K, Lindgren G, Mikko S, Millon L, Wade C, Schubert M, Orlando L, Penedo M C, Barsh G S, Andersson L. Regulatory mutations in $T B X 3$ disrupt asymmetric hair pigmentation that underlies Dun camouflage color in horses. Nature Genetics, 2016, 48(2): 152-158

8. Li B, He X, Zhao Y, Zhao Q, Unierhu, Bai D, Manglai D. Tyrosinase-related protein 1 (TYRPI) gene polymorphism and skin differential expression related to coat color in Mongolian horse. Livestock Science, 2014, 167: 58-64

9. Kerje S, Lind J, Schütz K, Jensen P, Andersson L. Melanocortin 1receptor (MC1R) mutations are associated with plumage colour in chicken. Animal Genetics, 2003, 34(4): 241-248

10. Fontanesi L, Dall'Olio S, Beretti F, Portolano B, Russo V. Coat colours in the Massese sheep breed are associated with mutations in the agouti signalling protein $(A S I P)$ and melanocortin 1 receptor (MC1R) genes. Animal, 2011, 5(1): 8-17

11. Kijas J M H, Wales R, Törnsten A, Chardon P, Moller M, Andersson L. Melanocortin receptor 1 (MC1R) mutations and coat color in pigs. Genetics, 1998, 150(3): 1177-1185

12. Petersen J L, Mickelson J R, Rendahl A K, Valberg S J, Andersson L S, Axelsson J, Bailey E, Bannasch D, Binns M M, Borges A S, Brama P, da Câmara Machado A, Capomaccio S, Cappelli K, Cothran E G, Distl O, Fox-Clipsham L, Graves K T, Guérin G, Haase B, Hasegawa T, Hemmann K, Hill E W, Leeb T, Lindgren G, Lohi H, Lopes M S, McGivney B A, Mikko S, Orr N, Penedo M C, Piercy R J, Raekallio M, Rieder S, Røed K H, Swinburne J, Tozaki T, Vaudin M, Wade C M, McCue M E. Genome-wide analysis reveals selection for important traits in domestic horse breeds. PLoS Genetics, 2013, 9(1): e1003211

13. Rieder S, Taourit S, Mariat D, Langlois B, Guérin G. Mutations in the agouti (ASIP), the extension (MC1R), and the brown (TYRP1) loci and their association to coat color phenotypes in horses (Equus caballus). Mammalian Genome: Official Journal of the International Mammalian Genome Society, 2001, 12(6): 450-455

14. Reissmann M, Musa L, Zakizadeh S, Ludwig A. Distribution of coat-color-associated alleles in the domestic horse population and 
Przewalski's horse. Journal of Applied Genetics, 2016, 57(4): 519525

15. Sundström E, Imsland F, Mikko S, Wade C, Sigurdsson S, Pielberg G R, Golovko A, Curik I, Seltenhammer M H, Sölkner J, LindbladToh K, Andersson L. Copy number expansion of the STX17 duplication in melanoma tissue from Grey horses. BMC Genomics, 2012, 13(1): 365

16. Jiang L, Campagne C, Sundström E, Sousa P, Imran S, Seltenhammer M, Pielberg G, Olsson M J, Egidy G, Andersson L, Golovko A. Constitutive activation of the ERK pathway in melanoma and skin melanocytes in Grey horses. BMC Cancer, 2014, 14(1): 857

17. Teixeira R B, Rendahl A K, Anderson S M, Mickelson J R, Sigler D, Buchanan B R, Coleman R J, McCue M E. Coat color genotypes and risk and severity of melanoma in gray quarter horses. Journal of Veterinary Internal Medicine, 2013, 27(5): 1201-1208

18. Stefaniuk-Szmukier M, Ropka-Molik K, Piórkowska K, Szmatoła T, Długosz B, Pisarczyk W, Bugno-Poniewierska M. Variation in $T B X 3$ gene region in dun coat color polish konik horses. Journal of Equine Veterinary Science, 2017, 49: 60-62

19. Gao K X, Chen N B, Liu W J, Li R, Lan X Y, Chen H, Lei C Z, Dang R H. Frequency of gray coat color in native Chinese horse breeds. GMR, 2015, 14(4): 14144-14150

20. Petersen J L, Valberg S J, Mickelson J R, McCue M E. Haplotype diversity in the equine myostatin gene with focus on variants associated with race distance propensity and muscle fiber type proportions. Animal Genetics, 2014, 45(6): 827-835

21. Hill E W, Gu J, Eivers S S, Fonseca R G, McGivney B A, Govindarajan P, Orr N, Katz L M, MacHugh D E. A sequence polymorphism in MSTN predicts sprinting ability and racing stamina in thoroughbred horses. PLoS One, 2010, 5(1): e8645

22. Shin D H, Lee J W, Park J E, Choi I Y, Oh H S, Kim H J, Kim H. Multiple genes related to muscle identified through a joint analysis of a two-stage genome-wide association study for racing performance of 1156 thoroughbreds. Asian-Australasian Journal of Animal Sciences, 2015, 28(6): 771-781

23. Li R, Liu D H, Cao C N, Wang S Q, Dang R H, Lan X Y, Chen H, Zhang T, Liu W J, Lei C Z. Single nucleotide polymorphisms of myostatin gene in Chinese domestic horses. Gene, 2014, 538(1): $150-154$

24. Moon S, Lee J W, Shin D, Shin K Y, Kim J, Choi I Y, Kim J, Kim H. A Genome-wide scan for selective sweeps in racing horses. Asian-Australasian Journal of Animal Sciences, 2015, 28(11): $1525-1531$

25. Andersson L S, Larhammar M, Memic F, Wootz H, Schwochow D, Rubin C J, Patra K, Arnason T, Wellbring L, Hjälm G, Imsland F, Petersen J L, McCue M E, Mickelson J R, Cothran G, Ahituv N, Roepstorff L, Mikko S, Vallstedt A, Lindgren G, Andersson L, Kullander K. Mutations in DMRT3 affect locomotion in horses and spinal circuit function in mice. Nature, 2012, 488(7413): 642-646

26. Promerová M, Andersson L S, Juras R, Penedo M C, Reissmann M, Tozaki T, Bellone R, Dunner S, Hořín P, Imsland F, Imsland P, Mikko S, Modrý D, Roed K H, Schwochow D, Vega-Pla J L, Mehrabani-Yeganeh H, Yousefi-Mashouf N, G Cothran E, Lindgren G, Andersson L. Worldwide frequency distribution of the 'Gait keeper' mutation in the DMRT3 gene. Animal Genetics, 2014, 45(2):

\section{4-282}

27. Fegraeus K J, Johansson L, Mäenpää M, Mykkänen A, Andersson L S, Velie B D, Andersson L, Árnason T, Lindgren G. Different DMRT3 genotypes are best adapted for harness racing and riding in finnhorses. Journal of Heredity, 2015 106(6): 734-740

28. Jäderkvist K, Andersson L S, Johansson A M, Árnason T, Mikko S, Eriksson S, Andersson L, Lindgren G. The DMRT3 'Gait keeper' mutation affects performance of Nordic and Standardbred trotters. Journal of Animal Science, 2014, 92(10): 4279-4286

29. Kristjansson T, Bjornsdottir S, Sigurdsson A, Andersson L S, Lindgren G, Helyar S J, Klonowski A M, Arnason T. The effect of the 'Gait keeper' mutation in the DMRT3 gene on gaiting ability in Icelandic horses. Journal of Animal Breeding and Genetics, 2014, 131(6): 415-425

30. Han H, Zeng L, Dang R, Lan X, Chen H, Lei C. The DMRT3 gene mutation in Chinese horse breeds. Animal Genetics, 2015, 46(3): 341-342

31. Revold T, Mykkänen A K, Karlström K, Ihler C F, Pösö A R, EssénGustavsson B. Effects of training on equine muscle fibres and monocarboxylate transporters in young Coldblooded Trotters. Equine Veterinary Journal, 2010, 42(38): 289-295

32. Solé M, Cervantes I, Gutiérrez J P, Gómez M D, Valera M. Estimation of genetic parameters for morphological and functional traits in a Menorca horse population. Spanish Journal of Agricultural Research, 2014, 12(1): 125

33. Brard S, Ricard A. Genome-wide association study for jumping performances in French sport horses. Animal Genetics, 2015, 46(1): $78-81$

34. Makvandi-Nejad S, Hoffman G E, Allen J J, Chu E, Gu E, Chandler A M, Loredo A I, Bellone R R, Mezey J G, Brooks S A, Sutter N B. Four loci explain $83 \%$ of size variation in the horse. PLoS One, 2012, 7(7): e39929

35. Frischknecht M, Jagannathan V, Plattet $P$, Neuditschko M, SignerHasler H, Bachmann I, Pacholewska A, Drögemüller C, Dietschi E, Flury C, Rieder S, Leeb T. A non-synonymous HMGA2 variant decreases height in shetland ponies and other small horses. PLoS One, 2015, 10(10): $\mathrm{e} 0140749$

36. Kader A, Li Y, Dong K, Irwin D M, Zhao Q, He X, Liu J, Pu Y, Gorkhali N A, Liu X, Jiang L, Li X, Guan W, Zhang Y, Wu D D, Ma $\mathrm{Y}$. population variation reveals independent selection toward small body size in chinese Debao pony. Genome Biology and Evolution, 2016, 8(1): 42-50

37. Brooks S A, Makvandi-Nejad S, Chu E, Allen J J, Streeter C, Gu E, McCleery B, Murphy B A, Bellone R, Sutter N B. Morphological variation in the horse: defining complex traits of body size and shape. Animal Genetics, 2010, 41(Suppl 2): 159-165

38. Petersen J L, Mickelson J R, Rendahl A K, Valberg S J, Andersson L S, Axelsson J, Bailey E, Bannasch D, Binns M M, Borges A S, Brama P, da Câmara Machado A, Capomaccio S, Cappelli K, Cothran E G, Distl O, Fox-Clipsham L, Graves K T, Guérin G, Haase B, Hasegawa T, Hemmann K, Hill E W, Leeb T, Lindgren G, Lohi H, Lopes M S, McGivney B A, Mikko S, Orr N, Penedo M C, Piercy R J, Raekallio M, Rieder S, Røed K H, Swinburne J, Tozaki T, Vaudin M, Wade C M, McCue M E. Genome-wide analysis reveals selection for important traits in domestic horse breeds. PLoS Genetics, 2013, 9(1): e1003211 
39. Signer-Hasler H, Flury C, Haase B, Burger D, Simianer H, Leeb T, Rieder S. A genome-wide association study reveals loci influencing height and other conformation traits in horses. PLoS One, 2012, 7 (5): e37282

40. Tetens J, Widmann P, Kühn C, Thaller G. A genome-wide association study indicates LCORL/NCAPG as a candidate locus for withers height in German Warmblood horses. Animal Genetics, 2013, 44(4): 467-471

41. Metzger J, Schrimpf R, Philipp U, Distl O. Expression levels of LCORL are associated with body size in horses. PLoS One, 2013, 8 (2): e56497

42. Metzger J, Gast A C, Schrimpf R, Rau J, Eikelberg D, Beineke A, Hellige M, Distl O. Whole-genome sequencing reveals a potential causal mutation for dwarfism in the Miniature Shetland pony. Mammalian genome: Official Journal of the International Mammalian Genome Society, 2017, 28(3-4): 143-151

43. Rafati N, Andersson L S, Mikko S, Feng C, Raudsepp T, Pettersson J, Janecka J, Wattle O, Ameur A, Thyreen G, Eberth J, Huddleston J, Malig M, Bailey E, Eichler E E, Dalin G, Chowdary B, Andersson
L, Lindgren G, Rubin C J. Large deletions at the SHOX locus in the pseudoautosomal region are associated with skeletal atavism in Shetland Ponies. G3: Genes, Genomes, Genetics, 2016, 6(7): 22132223

44. Hendrickson S L. A genome wide study of genetic adaptation to high altitude in feral Andean Horses of the páramo. BMC Evolutionary Biology, 2013, 13(1): 273

45. Librado P, Der Sarkissian C, Ermini L, Schubert M, Jónsson H, Albrechtsen A, Fumagalli M, Yang M A, Gamba C, Seguin-Orlando A, Mortensen C D, Petersen B, Hoover C A, Lorente-Galdos B, Nedoluzhko A, Boulygina E, Tsygankova S, Neuditschko M, Jagannathan V, Thèves C, Alfarhan A H, Alquraishi S A, AlRasheid K A, Sicheritz-Ponten T, Popov R, Grigoriev S, Alekseev A N, Rubin E M, McCue M, Rieder S, Leeb T, Tikhonov A, Crubézy E, Slatkin M, Marques-Bonet T, Nielsen R, Willerslev E, Kantanen J, Prokhortchouk E, Orlando L. Tracking the origins of Yakutian horses and the genetic basis for their fast adaptation to subarctic environments. Proceedings of the National Academy of Sciences of the United States of America, 2015, 112(50): E6889-E6897 